TABLe II.-Certain Known (or Probable) Effects of Cortisone

\begin{tabular}{|c|c|c|c|c|c|}
\hline Metabolic & Interendocrine & Neuromuscular & $\begin{array}{l}\text { Immunological and } \\
\text { Serological }\end{array}$ & Cytological & Enzymological \\
\hline $\begin{array}{l}\text { Increases gluconeogenesis } \\
\text { Lowers renal threshold } \\
\text { for glucose } \\
\text { Opposes the action of } \\
\text { insulin } \\
\text { Increases mobilization } \\
\text { and utilization of fat } \\
\text { Increases protein cata- } \\
\text { bolism, urinary nitro- } \\
\text { gen, and urinary uric } \\
\text { acid } \\
\text { Increases deposition of } \\
\text { hepatic glycogen } \\
\text { May bring about reten- } \\
\text { tion of sodium } \\
\text { Increases urinary excre- } \\
\text { tion of chloride and } \\
\text { potassium } \\
\text { May increase calcium and } \\
\text { phosphorus excretion }\end{array}$ & $\begin{array}{l}\text { May either depress thyroid } \\
\text { activity (probably via dim- } \\
\text { inished pituitary production } \\
\text { of thyrotropic hormone) or } \\
\text { increase sensitivity of tissues } \\
\text { peripherally to thyroid hor- } \\
\text { mone } \\
\text { I n r e a s es insulin require- } \\
\text { ment. In individuals with } \\
\text { normal pancreatic reserve } \\
\text { this requirement is ade- } \\
\text { quately met, but in latent or } \\
\text { overt diabetes additional } \\
\text { insulin must be administered } \\
\text { Relative hypoglycaemia may } \\
\text { occur after withdrawal of } \\
\text { cortisone } \\
\text { Restores normal diuretic re- } \\
\text { sponse to ingested water in } \\
\text { Addison's disease } \\
\text { May delay or inhibit men- } \\
\text { struation, probably via de- } \\
\text { pression of pituitary gonado- } \\
\text { tropic activity }\end{array}$ & $\begin{array}{l}\text { Restores capacity of mus- } \\
\text { cle for work in adrenal- } \\
\text { ectomized animals } \\
\text { May cause increased acti- } \\
\text { vity in electroencephalo- } \\
\text { gram (increase in fre- } \\
\text { quency of alpha waves) } \\
\text { or appearance of abnor- } \\
\text { mal slow rhythms } \\
\text { M a y res t o r e electro- } \\
\text { encephalographic pat- } \\
\text { tern to normal in } \\
\text { Addison's disease } \\
\text { May induce euphoria and } \\
\text { increased psychomotor } \\
\text { activity } \\
\text { May precipitate psychotic } \\
\text { reaction (probably only } \\
\text { in predisposed indivi- } \\
\text { duals) } \\
\text { May increase muscle } \\
\text { strength (in rheumatoid } \\
\text { arthritis) or may cause } \\
\text { muscle weakness (pro- } \\
\text { bably only in cases of } \\
\text { hypopotassaemia) }\end{array}$ & $\begin{array}{l}\text { Tends to bring about a } \\
\text { restoration of normal } \\
\text { A.-G. ratio in disease } \\
\text { Diminishes antibody re- } \\
\text { sponse to typhoid anti- } \\
\text { gen in rabbits } \\
\text { Diminishes or abolishes } \\
\text { tuberculin reaction } \\
\text { May prevent vascular } \\
\text { lesions otherwise re- } \\
\text { sulting from injection } \\
\text { of D.C.A. (rats) or } \\
\text { heterologous serum } \\
\text { (rabbits) , } \\
\text { Prevents or reduces tissue } \\
\text { reaction to chemical } \\
\text { irritants (guinea-pigs) } \\
\text { May inhibit formation of } \\
\text { histamine }\end{array}$ & $\begin{array}{l}\text { Produces lymphopenia } \\
\text { (some species) and } \\
\text { eosinopenia in peri- } \\
\text { pheral blood } \\
\text { M a in creas e tissue } \\
\text { eosinophils and meta- } \\
\text { plasia of fibroblasts } \\
\text { into eosinophils } \\
\text { Inhibits fibroplasia } \\
\text { I n r a es growth of } \\
\text { macrophages in tissue } \\
\text { culture } \\
\text { Stimulates reticulocyte } \\
\text { production or release } \\
\text { May bring about poly- } \\
\text { cythaemia } \\
\text { May increase neutrophils } \\
\text { in peripheral blood } \\
\text { Causes involution of } \\
\text { lymphoid tissue and } \\
\text { of certain neoplastic } \\
\text { tissues }\end{array}$ & $\begin{array}{l}\text { Diminishes hygluroni- } \\
\text { dase activity } \\
\text { Probably reduces } \\
\text { blood glutathione } \\
\text { May be involved in } \\
\text { enzyme sys tems } \\
\text { concerned with pig- } \\
\text { mentation of skin } \\
\text { Increases arginase in } \\
\text { liver and kidney of } \\
\text { mice } \\
\text { I c re a s es urinary } \\
\text { excretion of uro- } \\
\text { pepsin in patients } \\
\text { with A d'd is o n's } \\
\text { disease }\end{array}$ \\
\hline
\end{tabular}

research effort which may be expected to bring aboụt a new concept of the nature of disease itself.

It seems likely that cortisone does not act therapeutically through a single circumscribed mechanism, but that this action must involve the many known physiological properties of the hormone as well as various undiscovered effects of this substance on the chemical processes of organs, tissues, and cells of the normal and the diseased organism. At the present time we have information indicating that (1) cortisone and/or compound $\mathrm{F}$ is involved in the metabolism of carbohydrate, protein, and fat ; (2) it is necessary to the normal function of certain endocrine organs; (3) it exerts profound effects on neuromuscular metabolism; (4) it has distinct immunological effects; (5) it can bring about remarkable cytological changes ; and (6) it is involved in several specific enzyme systems (see Table II).

It is for future research to determine which of these effects, or others, are fundamentally associated with the therapeutic activity of cortisone, and which ones are associated only coincidentally. The tendency to oversimplify the problem must be avoided, since it is clear that the hormone is implicated, directly or indirectly, in a large number of the physiochemical processes of the vertebrate organism.

\section{Looking Ahead}

The body of knowledge concerning the exact value of cortisone in the treatment of the variety of diseases discussed above is rapidly growing, as is the understanding of its pharmaco-physiological effects. Steadily increasing supplies of cortisone are becoming available, so that clinical and experimental studies are rapidly expanding in number and scope. So, too, the periods of observation on patients already treated are lengthening, and the results are becoming more measurable. Combined, these factors assure that a more exact appraisal of the effects of cortisone will shortly be possible.

A technical committee of the British Standards Institution has devised simple common names for certain pest-control products. A list of 25 names is being circulated for comment among Government departments, manufacturers, and scientific societies before final publication. In order to pre-empt the use of these names as proprietary names, the list has been lodged with, and approved by, H.M. Patent Office.

\section{STREPTOMYCIN AND NEOMYCIN* AN ANTIBIOTIC APPROACH TO TUBERCULOSIS}

\author{
BY
}

SELMAN A. WAKSMAN, Ph.D.

(From the Department of Microbiology, Rutgers University, New Brunswick, N.J., U.S.A.)

\begin{abstract}
"This attempt to place between the covers of a book the record of a drug discovered less than five years ago is a daring and unprecedented one. It suggests a wealth of knowledge, established despite the haste of its gathering. It is particularly daring in the instance of tuberculosis, a disease so chronic in its habit that phthisiologists rarely do more than describe its victims as 'apparently' cured, and so multiple in its manifestations that it required the discovery of the tubercle bacillus to unify its many forms beneath a single name."-Walker, Hinshaw, and Barnwell (Waksman, 1949).
\end{abstract}

\section{Historical}

The history of tuberculosis is as old as that of man himself. It was, however, the discovery of the causative agent of this disease, Mycobacterium tuberculosis, by Robert Koch that stimulated the search for "cures" of this "white plague" of man. Most of these, ranging from the tuberculin of Koch himself to the much publicized "gold cure" of recent years, led to serious disappointments. The antibiotics, or those compounds of microbial origin that have the capacity of inhibiting and even of destroying in very dilute solutions the growth of other microbes, especially the causative agents of disease, have given new hope for a final solution of this ancient disease. Although most of the antibiotics are not very effective against the acid-fast bacteria, a few have proved to be highly effective against the mycobacteria, including the tuberculosis organism. Side by side with the discovery of antimycobacterial agents of microbial origin, progress has also been made in the use of synthetic compounds which are non-toxic but still active enough to justify their use in chemotherapy.

*A paper to be read at the First Internationa Congress of Internal Medicine, Paris, September 11-14, 1950 
The utilization of micro-organisms as well as their products for the treatment of tuberculosis is not of recent origin. The first attempt at such treatment was made soon after the tuberculosis organism was isolated. Cantani tried in 1885 to utilize living saprophytic bacteria for combating tuberculosis; he was soon followed by Babes, who in 1888 used bacterial products. Later, Rappin and Vaudremer, in 1912-13, treated many patients with products of bacterial metabolism and with metabolic products and cell constituents of fungi, respectively. In general, the history of bacteriotherapy of tuberculosis is a long one (Waksman, 1947). Numerous investigators established beyond question that various saprophytic and pathogenic micro-organisms have the capacity to inhibit the growth of and even to destroy the $M$. tuberculosis. Further studies brought out the, fact that this is due primarily to certain well-defined chemical compounds which these microorganisms are able to produce when grown in artificial culture media and which are now known as antibiotics.

It has been definitely established that the ability to form antibiotics which are active upon the $M$. tuberculosis is widely distributed among various groups of microorganisms. At least 16 products of fungi, 11 bacterial preparations, and 10 antibiotics of actinomycetes have been isolated and are now well recognized. They are listed in Table I. Most of these compounds or preparations proved

TABLE I.-Production by Different Micro-organisms of Antibiotics Possessing Antituberculosis Properties

\begin{tabular}{|c|c|c|}
\hline Fungi & Actinomycetes & Bacteria \\
\hline $\begin{array}{l}\text { Aspergillic acid } \\
\text { Aspergillin } \\
\text { Biformin } \\
\text { Clitocybine } \\
\text { Diploicin } \\
\text { Enniatin } \\
\text { Gliotoxin } \\
\text { Helvolic acid (fumigacin) } \\
\text { Javanicin } \\
\text { Lactaroviolin } \\
\text { Lateritiin } \\
\text { Mycocidin } \\
\text { Nebularin } \\
\text { Polyporin } \\
\text { Usnic acid } \\
\text { Ustin }\end{array}$ & $\begin{array}{l}\text { Actinomycin } \\
\text { Anti-smegmatis factor } \\
\text { Litmocidin } \\
\text { Mycomycin } \\
\text { Neomycin } \\
\text { Nocardin } \\
\text { Streptin } \\
\text { Streptothricin } \\
\text { Streptomycin } \\
\text { Mannosidostreptomycin }\end{array}$ & $\begin{array}{l}\text { Ayfivin } \\
\text { Bacillin } \\
\text { Endosubtilisin } \\
\text { Esperin } \\
\text { Eumycin } \\
\text { Gramicidin } \\
\text { Licheniformin } \\
\text { Micrococcin } \\
\text { Nisin } \\
\text { Pyolypic acid } \\
\text { Subtilin }\end{array}$ \\
\hline
\end{tabular}

to be, for one reason or another, quite unsuitable as chemotherapeutic agents. Some were too toxic, others were inactive or insufficiently active in the animal body. Some of them, however, gave definite promise of becoming important tools in combating tuberculosis. Most important of these proved to be streptomycin, an antibiotic produced by an actinomyces, Streptomyces griseus, which has already found extensive application in the therapy of tuberculosis.

\section{Antimycobacterial Properties of Streptomycin}

Streptomycin is highly active against various strains of M. tuberculosis (Waksman, 1949). The degree of sensitivity varies considerably, however, as shown in Table II. Of particular importance is the fact that upon contact with streptomycin, or upon continued administration, of this

TABLE II.-Comparative Effects of Neomycin and Streptomycin Upon the Growth of Different Mycobacteria (Waksman et al. 1949). Growth Inhibition in Units (for Neomycin) or in Micrograms (for Streptomycin) Per Millilitre of Broth After 14 Days Incubation

\begin{tabular}{|c|c|c|c|c|}
\hline Organism & & & Neomycin & Streptomycin \\
\hline 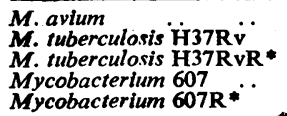 & $\begin{array}{l}\ddot{*} \\
\ddot{*} \\
\ddot{*}\end{array}$ & $\begin{array}{l}\cdots \\
\cdots \\
\cdots \\
\cdots\end{array}$ & $\begin{array}{c}0 \cdot 1-0 \cdot 3 \\
0 \cdot 2-1 \cdot 0 \\
0 \cdot 2-1 \cdot 0 \\
0 \cdot 1 \\
0 \cdot 25\end{array}$ & $\begin{array}{c}10 \cdot 0 \\
1 \cdot 0-5 \cdot 0 \\
5,000 \\
0 \cdot 2-0 \cdot 4 \\
300\end{array}$ \\
\hline
\end{tabular}

drug to diseased persons, some of the strains tend to develop resistance to the antibiotic. This is shown in Table III, in which the sensitivity of different freshly

TABLE III.-Comparative Effects of Streptomycin and Neomycin Upon Freshly Isolated Strains of M. tuberculosis (Waksman et al., 1949)

\begin{tabular}{c|c|c|c}
\hline \multirow{3}{*}{$\begin{array}{c}\text { Strain } \\
\text { No. }\end{array}$} & \multirow{3}{*}{ Source of Culture } & \multicolumn{2}{|c}{$\begin{array}{c}\text { Amount of Antibiotic Required to } \\
\text { Inhibit Growth in Liquid Medium }\end{array}$} \\
\cline { 2 - 3 } & & Streptomycin & Neomycin \\
\hline & & $\mu \mathrm{m} . / \mathrm{ml}$. & units/ml. \\
100 & Sinus left hip & 1 to 5 & $<0.5$ \\
500 & Sinus left flank & 1 to 5 & $<0.5$ \\
575 & Bladder & 100 & $<0.5$ \\
910 & Gastric & 1 to 5 & $<0.5$ \\
209 & Sputum & 1 to 5 & $<0.5$ \\
684 & Urine & $>100$ & $<0.5$ \\
\hline
\end{tabular}

isolàted strains of the pathogen to streptomycin, as compared with neomycin, is presented.

As is shown below, the search for a second antibiotic was stimulated by this limitation of streptomycinnamely, the rapidity with which bacteria develop resistance to it. Both the streptomycin-sensitive and streptomycinresistant strains of different mycobacteria are sensitive to neomycin. This is true of saprophytic and pathogenic forms, whether the resistance is natural or is acquired by contact with streptomycin.

\section{Search for New Agents}

The discovery of streptomycin, and its extensive application in the treatment of various forms of tuberculosis, has aroused great interest on the part of bacteriologists, chemists, and clinicians, and has resulted in further extensive searches for new substances, microbial or synthetic in origin, which would overcome the limitations of streptomycin.

In the search for and selection of new antimicrobial agents, four postulates may be made (Waksman et al., 1949) :

1. These substances must be active, not only in vitro but also in vivo, against the specific micro-organisms. It is desirable that this activity be greater than that of other substances which are now recognized as useful or promising.

2. They must be active against those strains of the diseaseproducing micro-organisms which are not sensitive or which have become resistant to other chemotherapeutic agents.

3. They should not favour the development of resistance among sensitive bacteria ; at least, the new agents should permit lesser emergence of such resistance than existing agents.

4. They should be of low toxicity to animals, or at least they should be no more toxic than agents now used in chemotherapy.

Many organisms have been tested for their capacity to produce such antibiotic agents. Various substances have been isolated in our laboratory since the isolation of streptomycin was reported in 1944, and their activity in vitro and in vivo has been determined. Of these, only one, neomycin, was found to satisfy the postulates. This conclusion was reached after extensive comparative studies of the effect of streptomycin and neomycin upon various bacteria. These included test-tube studies of both saprophytic and pathogenic mycobacteria and animal studies of both antibiotics against various Gram-positive and Gramnegative bacteria. These studies brought out the following facts :

1. Neomycin is more active than streptomycin against both the saprophytic Mycobacterium 607 and the human and animal pathogenic strains of $M$. tuberculosis.

2. Neomycin is as active against the streptomycin-resistant strains of the above organisms as against the sensitive ones. 
3. Neomycin favours to a far less degree than does streptomycin the development of resistant strains of mycobacteria; it is true that on prolonged serial transfer of large numbers of cells a considerable increase in resistance may be obtained, but the rate of increase is much slower than in the case of streptomycin.

4. Neomycin is characterized by a relatively low toxicity in animals and has a high therapeutic index.

Before examining the limited experimental and clinical data now available for neomycin, it may be of interest to summarize briefly the very extensive literature on the effect of streptomycin upon tuberculosis. For a detailed review reference can be made to the various works dealing with this subject (Fanconi and Löffler, 1948 ; Florey et al., 1949 ; Riggins and Hinshaw, 1949 ; Waksman, 1949).

\section{Effect of Streptomycin in Experimental and Clinical Tuberculosis}

In the first studies on the treatment of experimental tuberculous infections in guinea-pigs with streptomycin the results obtained were strikingly better than those previously reported with the use of various other chemotherapeutic agents. This is brought out in Fig. 1. Feldman and Hin-

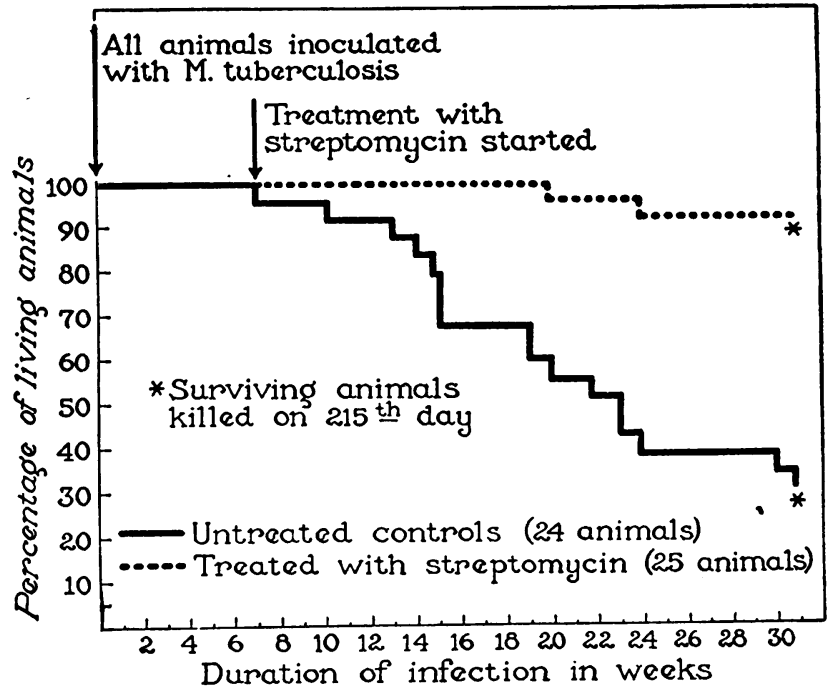

FIG. 1.-Comparative survival times of treated and untreated groups of guinea-pigs (from Feldman, Hinshaw, and Mann, 1945).

shaw were soon able to state emphatically : "The evidence obtained from the many studies of the effect of streptomycin on the natural course of experimental tuberculosis in animals amply justifies the conclusion that this antibiotic is a highly potent antagonistic agent for tuberculous infections in animals produced by fully virulent tubercle bacilli of human or of bovine type."

Clinical investigations soon followed (Hinshaw and Feldman, 1945; Hinshaw et al., 1946a, 1946b). The first results obtained with streptomycin proved to be encouraging. It is now barely five years since the first clinical cases were reported and since the first attempt was made to manufacture streptomycin in sufficient amounts for large-scale clinical evaluation; a wealth of information which permits certain broad generalizations has already accumulated.

In general, the laboratory demonstrations of the effectiveness of streptomycin in vitro, followed by the experimental proof of its usefulness in experimental animals, were fully substantiated by numerous clinical investigations. The large-scale studies conducted in England by the Medical Research Council (1948), and in the United States by the Veterans Administration (Council on Pharmacy and Chemistry, 1950) and the American Trudeau Society (1950), produced adequate evidence that an agent for the treatment of tuberculosis was finally available. Although many hundreds of drugs were previously reported to control the tubercle bacillus in the culture tube, none were able to do so in the animal body. Many drugs that have been effective against the infection in animals were found to be impracticable against the same disease in man. In the case of streptomycin the analogy from laboratory to animal to man held well. It was only in the clinic, however, that investigators finally learned of the potentialities of streptomycin, on the one hand, and of its limitations and dangers on the other.

The clinical usefulness of streptomycin has been carefully summarized by Riggins and Hinshaw (1949) and by Walker, Hinshaw, and Barnwell (Waksman, 1949).

In submitting its report to the Council on Pharmacy and Chemistry (1950), the committee in charge of the work at the Veterans Administration emphasized the importance of combining surgical procedures with chemotherapy. The use of daily doses of $1 \mathrm{~g}$. or less has decidedly reduced the incidence of toxic manifestations. The development of resistant micro-organisms was delayed, especially by the combined administration with para-aminosalicylic acid.

The American Trudeau Society Committee (1950) recommended for adults $1 \mathrm{~g}$. of streptomycin, administered in a single dose intramuscularly, or 1 or $2 \mathrm{~g}$. of dihydrostreptomycin in one or two injections. In miliary tuberculosis and tuberculous meningitis in adults, 2 or $3 \mathrm{~g}$. a day, given intramuscularly in two or three doses of $1 \mathrm{~g}$. each, was recommended. To overcome the emergence of streptomycin-resistant organisms, it has been recommended that streptomycin be administered at greater intervals, as $1 \mathrm{~g}$. every third day or twice a week, or that its daily administration be combined with para-aminosalicylic acid.

It may be of interest to consider in somewhat greater detail certain special forms of tuberculosis.

\section{Meningeal and Acute Miliary Tuberculosis}

Since they were first recognized, these two types of tuberculosis have involved a mortality rate of $100 \%$. The time between onset of disease and death was measured in weeks, especially in meningitis. These two forms provided, therefore, an ideal testing ground for the efficacy of streptomycin. It has fully justified itself. Its ability to suppress or destroy the tubercle bacillus was demonstrated. The effectiveness of streptomycin is now generally agreed on by investigators in the U.S.A., in England, and in other European countries. In one series of 100 patients with proved diagnoses, 24 were alive between 14 and 26 months after treatment had been instituted. These results are given in Table IV.

TABLE IV.-Effect of Streptomycin on Acute Miliary and Meningeal Tuberculosis (From Walker, Hinshaw, and Barnweli-Waksman, 1949)

\begin{tabular}{|c|c|c|c|c|c|c|}
\hline \multirow{2}{*}{ Nature of Disease } & \multirow{2}{*}{$\begin{array}{l}\text { No. of } \\
\text { Patients }\end{array}$} & \multirow{2}{*}{$\begin{array}{l}\text { No. } \\
\text { Living }\end{array}$} & \multicolumn{4}{|c|}{$\begin{array}{l}\text { No. Dead After Start of } \\
\text { Treatment in Months }\end{array}$} \\
\hline & & & $0-1.5$ & $1 \cdot 5-6$ & $>6$ & Total \\
\hline $\begin{array}{l}\text { Acute miliary } \\
\text { Meningeal } \\
\text { Miliary and meningeal } \\
\text { Meningeal developing } \\
\text { during or after treat- } \\
\text { ment for miliary ... }\end{array}$ & $\begin{array}{l}19 \\
43 \\
25 \\
\\
13\end{array}$ & $\begin{array}{r}12 \\
9 \\
2 \\
1\end{array}$ & $\begin{array}{r}3 \\
16 \\
14 \\
3\end{array}$ & $\begin{array}{r}2 \\
11 \\
6\end{array}$ & $\begin{array}{l}2 \\
7 \\
3\end{array}$ & $\begin{array}{r}7 \\
34 \\
23 \\
\end{array}$ \\
\hline Total & 100 & 24 & 36 & 23 & 17 & 76 \\
\hline
\end{tabular}

- All patients still living 14 to 26 months after start of treatment. 


\section{Pulmonary Tuberculosis}

Pulmonary tuberculosis is commonly considered, both in incidence and in the number of lives it takes, as one of the most serious forms. Since 1900 the mortality rate of tuberculosis has been reduced in the U.S.A. to $20 \%$ of its previous rate. In 1942, however, 52,000 deaths were still ascribed to tuberculosis, and of these $92 \%$ were due to pulmonary disease. The situation is worse in many European and Asiatic countries, particularly since the recent war. The prolongation of life in patients with meningeal and miliary tuberculosis was ample evidence that streptomycin had a definite effect on tuberculosis. The chronic nature of pulmonary tuberculosis suggests that years will pass before the effectiveness of streptomycin can be evaluated by its effect on the mortality rate.

In the relatively short period since its introduction, however, there has been substantial agreement among investigators that certain immediate results may be expected from its use. The question of toxicity and the development of bacterial resistance were the two controlling factors in establishing the most desirable duration of treatment. Originally a period of 120 days was selected. To lessen the incidence of resistance a decrease in duration of treatment has often been recommended. A reduction in efficacy did not seem to accompany a reduction in duration of treatment to 60 days. A further reduction to 42 days appeared to decrease the efficacy of streptomycin but certainly did not destroy it. The tendency over the last two years has been to reduce the daily dosage of streptomycin from $2 \mathrm{~g}$. to $1 \mathrm{~g}$. or even to $0.5 \mathrm{~g}$. and to reduce the period of treatment from 120 days to 60 days or even less. The first is an attempt to avoid toxicity, and the second to reduce the incidence of resistance.

In a comprehensive study of the effectiveness of streptomycin in tuberculosis carried out under the auspices of the British Medical Research Council (1948), the conclusion was reached that the course of bilateral acute progressive disease can be halted by streptomycin therapy :

"Fifty-one per cent. of the streptomycin-treated patients showed considerable improvement radiologically when comparison was made with their chest radiographs taken on

TABLE V.-Assessment of Radiological Appearance at Six Months as Compared with Appearance on Admission (Medical Research Council, 1948)

\begin{tabular}{|c|c|c|c|c|}
\hline \multirow[b]{2}{*}{ Radiological Assessment } & \multicolumn{2}{|c|}{ Streptomycin Group } & \multicolumn{2}{|c|}{ Control Group } \\
\hline & $\begin{array}{c}\text { No. of } \\
\text { Patients }\end{array}$ & $\%$ & $\begin{array}{c}\text { No. of } \\
\text { Patients }\end{array}$ & $\%$ \\
\hline 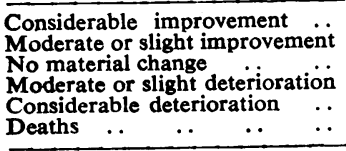 & $\begin{array}{r}28 \\
10 \\
2 \\
5 \\
6 \\
4\end{array}$ & $\begin{array}{r}51 \\
18 \\
4 \\
9 \\
11 \\
7 \\
\end{array}$ & $\begin{array}{r}4 \\
13 \\
3 \\
12 \\
6 \\
14 \\
\end{array}$ & $\begin{array}{r}8 \\
25 \\
6 \\
23 \\
11 \\
27\end{array}$ \\
\hline Total $\ldots \quad \ldots$ & 55 & 100 & 52 & 100 \\
\hline
\end{tabular}

TABLE VI-Changes in the Radiological Picture (Medical Research Council, 1948)

\begin{tabular}{|c|c|c|c|c|c|c|}
\hline \multirow{2}{*}{$\begin{array}{l}\text { Radiological } \\
\text { Assessment }\end{array}$} & \multicolumn{2}{|c|}{$\begin{array}{l}\text { Admission to } \\
\text { End of 2nd Month }\end{array}$} & \multicolumn{2}{|c|}{$\begin{array}{c}\text { Admission to } \\
\text { End of 4th Month }\end{array}$} & \multicolumn{2}{|c|}{$\begin{array}{l}\text { Admission to } \\
\text { End of 6th Month }\end{array}$} \\
\hline & $\mathbf{S}$ & C & $\mathbf{S}$ & C & $\mathbf{S}$ & C \\
\hline Total & $55(100 \%)$ & $52(100 \%)$ & $55(99 \%)$ & $52(99 \%)$ & $55(100 \%)$ & $52(100 \%)$ \\
\hline $\begin{array}{l}\text { Improvement: } \\
\text { Considerable } \\
\text { Slight or mod. } \\
\text { No change }\end{array}$ & $\begin{array}{c}8(14 \%) \\
34(62 \%) \\
7(13 \%)\end{array}$ & $\begin{array}{c}0 \\
3(6 \%) \\
27(52 \%)\end{array}$ & $\begin{array}{l}25(45 \%) \\
18(33 \%) \\
4(7 \%)\end{array}$ & $\begin{array}{c}0 \\
11(21 \%) \\
9(17 \%)\end{array}$ & $\begin{array}{l}28(51 \%) \\
10(18 \%) \\
2(4 \%)\end{array}$ & $\begin{array}{c}4(8 \%) \\
13(25 \%) \\
3(6 \%)\end{array}$ \\
\hline $\begin{array}{l}\text { Deterioration: } \\
\text { Slight or mod. } \\
\text { Considerable } \\
\text { Deaths } \quad . .\end{array}$ & $\begin{array}{l}5(9 \%) \\
1(2 \%) \\
0\end{array}$ & $\left|\begin{array}{c}14(27 \%) \\
6(11 \%) \\
2(4 \%)\end{array}\right|$ & $\begin{array}{c}4(7 \%) \\
4(7 \%) \\
0\end{array}$ & $\begin{array}{l}14(27 \%) \\
8(15 \%) \\
10(19 \%)\end{array}$ & $\begin{array}{l}5(9 \%) \\
6(11 \%) \\
4(7 \%)\end{array}$ & $\begin{array}{l}12(23 \%) \\
6(11 \%) \\
14(27 \%)\end{array}$ \\
\hline
\end{tabular}

admission. That streptomycin was the agent responsible for this result is attested by the presence in this trial of the control group of patients, among whom considerable improvement was noted in only four (8\%), and two of these four patients had improved only after collapse therapy. In other words, streptomycin therapy was. effecting what the patient's tissues alone could not do-checking the spread of the tubercle bacillus in one of its most favourable milieux."

A summary of these results is presented in Tables $V$ and VI.

\section{Draining Cutaneous Sinuses and Fistulae}

The ability of streptomycin to produce healing of tuberculous lesions of mucous and serous membranes, extending to lesions which involve the skin and its underlying tissues, was reported to be most remarkable. Prior to its use, cutaneous sinuses usually continued to drain for years. Their surgical treatment and closure were rarely possible. When treated with even small doses of streptomycin most sinuses were found to heal readily. The effect is so striking that it was not even considered necessary to have untreated controls. In the first clinical report of streptomycin therapy all sinuses in three patients healed during treatment. A much more extensive series of cases is summarized in Table VII.

TABLE VII.-Effect of Streptomycin Upon 382 Patients with 687 Draining Cutaneous Sinuses and Fistulae (From Walker, Hinshaw, and Barnwell-Waksman, 1949)

\begin{tabular}{|c|c|c|c|c|c|c|c|c|}
\hline \multirow[b]{2}{*}{$\begin{array}{l}\text { No. of } \\
\text { Patients }\end{array}$} & \multicolumn{2}{|c|}{ Treatment } & \multirow{2}{*}{$\begin{array}{l}\text { No. of } \\
\text { Sinuses } \\
\text { and } \\
\text { Fistulae }\end{array}$} & \multicolumn{5}{|c|}{ Observations at End of Treatment } \\
\hline & & ays & & $\begin{array}{l}\text { Healed } \\
\text { (Av. } \\
8 \text { wks.) }\end{array}$ & np. & & rse & $\begin{array}{c}\text { Recurrence } \\
\text { After } \\
\text { Healing }\end{array}$ \\
\hline $\begin{array}{r}126 \\
229 \\
15 \\
12\end{array}$ & $\begin{array}{l}1 . \mathrm{g} . \\
0.5 \mathrm{~g} . \\
0.2 \mathrm{~g}\end{array}$ & $\begin{array}{l}120 \\
120 \\
120\end{array}$ & $\begin{array}{r}403 \\
15 \\
12\end{array}$ & $\begin{array}{l}87.3 \% \\
69.6 \% \\
60 \% \\
83 \%\end{array}$ & \begin{tabular}{|c|}
$7.8 \%$ \\
$23.5 \%$ \\
$40 \%$ \\
$17 \%$
\end{tabular} & $\begin{array}{c}6.9 \% \\
0 \\
0\end{array}$ & \begin{tabular}{|c|}
$0.3 \%$ \\
0 \\
0 \\
0
\end{tabular} & $\begin{array}{c}2 \% \\
2 \% \\
0 \% \\
0\end{array}$ \\
\hline
\end{tabular}

On the basis of extensive experience in the use of streptomycin in tuberculosis, Walker, Hinshaw, and Barnwell (Waksman, 1949) concluded :

"The introduction of streptomycin into clinical medicine has been peculiarly exciting to phthisiologists. Not only have they never had an 'antibiotic' which was helpful in the treatment of tuberculosis in man, they have never had a proved effective drug of any sort. So far as chemotherapy is concerned, not only was their situation comparable to that of the syphilologist prior to the discovery of penicillin, it was worse than his position before the appearance of Ehrlich and arsenic. Phthisiologists have been dependent on rest in bed, which finds its climax in the 'lung immobilizer,' and, more recently, on collapse therapy,

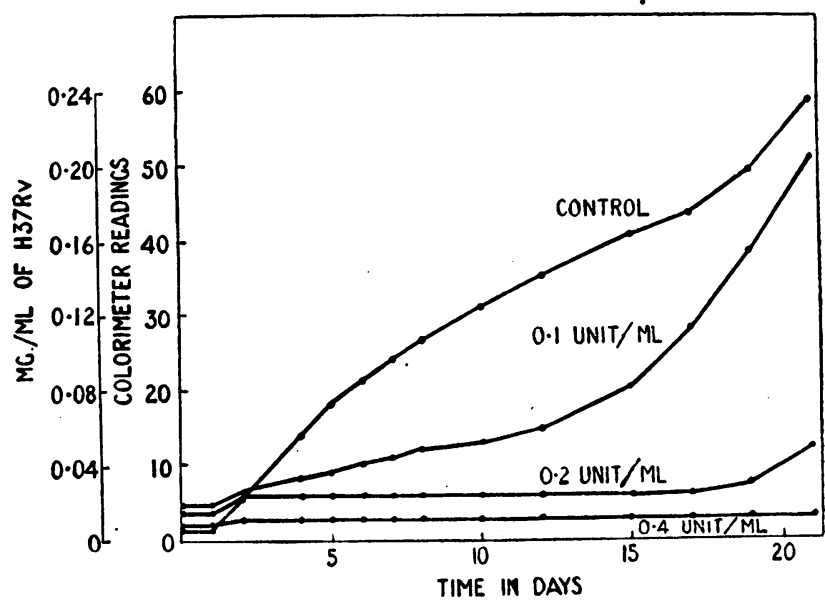

FIG. 2.-Effect of streptomycin upon the growth of H37Rv in Dubos medium (from Steenken and Wolinsky-Waksman, 1949). 
which has become most definitive in the form of excisional surgery.

"Chemotherapy is a radical departure from tradition in tuberculosis, and on this account it might have been anticipated that a tuberculostatic drug would be slowly, perhaps inaccurately, evaluated. In the case of streptomycin, this would appear not to have occurred. Within three years after publication of the first clinical paper describing its use, it has been possible to write a chapter of the present sort. This relatively rapid evaluation of a new drug-rapid for tuberculosis if not for pneumococcic pneumonia-is partly the result of experience gained from the investigation of other drugs in other diseases. It is partly a result of the employment, here and in England, of co-operative methods of investigation which have yielded data, reasonably uniform, rapidly, and in large amount ; methods which were used, perhaps for the first time, in the beautifully organized study on penicillin and syphilis which was initiated during the recent war."

\section{Development of Resistance to Streptomycin}

Attention has already been directed to the fact that among the most important problems involved in the use of streptomycin in tuberculosis is the development of resistance. This is brought out in a study of the effect of different concentrations of streptomycin upon the rate of growth of $M$. tuberculosis (Fig. 2). Steenken and Wolinsky (Waksman, 1949) emphasized that if the obstacle of streptomycin resistance could only be overcome the efficacy of the drug would be greatly increased. Whether by intermittent administration, or by combination of streptomycin with sulphones or para-aminosalicylic acid, or with some other tuberculostatic agent, it was found possible to delay

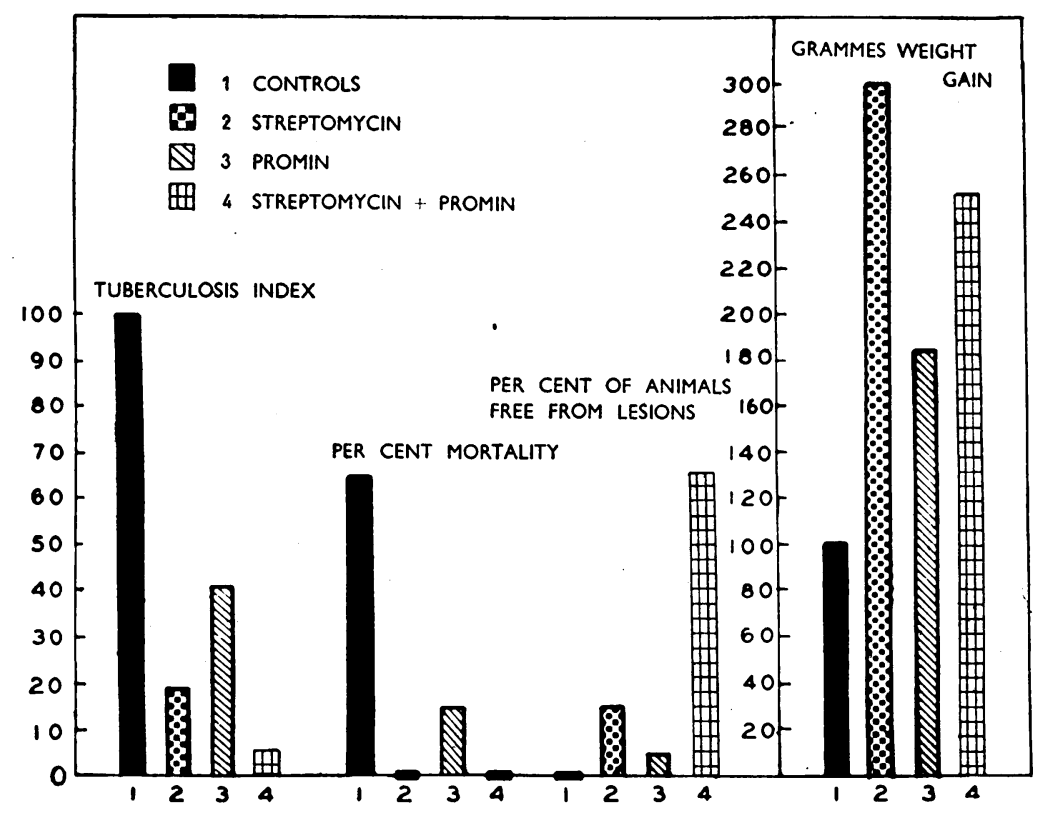

Fig. 3.-Effect of streptomycin alone and of streptomycin combined with promin upon experimental tuberculosis (from Smith and McClosky, 1945). the onset of streptomycin resistance. By shortening the course of therapy for pulmonary tuberculosis to four or six weeks the incidence of resistant strains is diminished. There is considerable variation in the development of drugresistant strains in the study of a large group of patients. Those who have definite pulmonary cavitation are more likely to produce resistant cultures than are those without cavitation. Patients who start treatment with a high bacillary count in the sputum show a greater tendency to yield drug-resistant cultures during streptomycin therapy than those with few organisms in the sputum. M. tuberculosis lodged in the central nervous system becomes resistant less readily than it does in the lungs.

The possibility of utilizing a combination of two antimycobacterial agents appears, for the present at least, to provide an answer to the problem of development of resistance. This is illustrated in Fig. 3. Another answer may be found in the search for new antibiotics. That this may finally be accomplished is illustrated by the use of neomycin (Fig. 4).

Whether the final solution of the tuberculosis problem will be an antibiotic or a combination of two antibiotics administered together or alternately, such as streptomycin with neomycin, or of an antibiotic and a synthetic compound, only the future can tell. The main conclusion, however, can now be reached: the chemotherapy of tuberculosis is possible. We may only hope that in the near 
future this dread disease, the "white plague" of mankind, will become but a memory in the history of man.

\section{Potentialities of Neomycin}

Information on the effect of neomycin in experimental and in clinical tuberculosis is still rather scanty. It is difficult to say what this antibiotic will do either in replacing or in supplementing streptomycin. The results presented here are based upon various published and unpublished reports of work done in a number of laboratories in the United States by G. L. Hobby, G. W. Rake, G. Duncan, O. Felsenfeld, and others.

Neomycin possesses a relatively low toxicity for experimental animals, the $\mathrm{LD}_{0}$ for $20 \mathrm{-g}$. mice being from 750 to 1,500 units. Daily injections of 1,200 to 2,000 units per mouse, administered subcutaneously in divided doses, produced no toxic manifestations. The drug is rapidly absorbed in the body and readily detected in the serum. It is rapidly excreted in the urine. It is highly active in experimental animals, daily dosages of 50 to 110 units per mouse being sufficient to suppress the tuberculous infections. It is just as active against streptomycin-resistant strains as against the sensitive strains.

With regard to the antituberculosis potential of neomycin, it is sufficient to say that in the animals infected with streptomycin-sensitive tubercle bacilli the results of neomycin therapy were, by and large, quite comparable to the results obtained with streptomycin.

One is impressed by the_antituberculosis potential of neomycin in experimental tuberculosis against infections induced by either streptomycin-sensitive or streptomycinresistant tubercle bacilli of the human type, as shown recently by Karlson, Gainer, and Feldman (1950). Until further pharmacological studies exonerate the drug of responsibility for direct or indirect damage to the kidneys, however, its use clinically must be approached with caution.

In human tuberculosis there is an immediate reaction consisting of lowering of the fever and a feeling of wellbeing. We have not seen toxic reactions with low doses. In two patients there was an increase of the N.P.N. and of the sedimentation rate, which disappeared when the drug was stopped. In some cases, however, definite evidence of a nephrotoxic and ototoxic action was reported.

The results recently published by Karlson, Gainer, and Feldman (1950) brought out the fact that neomycin is capable of producing a reversal of progressive tuberculosis in experimental animals. It is also effective against experimental infections due to streptomycin-resistant tubercle bacilli. A number of clinical cases, representing different forms of tuberculosis, are now being treated with neomycin, and it is expected that before very long a clear picture may be obtained of the potential place that this antibiotic may find in the treatment of tuberculosis. The possibility of combined action of neomycin and streptomycin or another antimicrobial agent is also receiving much consideration.

\section{What of the Future?}

The last decade has witnessed considerable progress in the chemotherapy of tuberculosis. From an unknown and questionable possibility, the treatment of this group of diseases by means of chemical agents has become a certainty. The introduction of antibiotics into the field of chemotherapy has opened new potentialities in the eradication of numerous infectious diseases, including tuberculosis. In the case of the latter, streptomycin pointed the way. Announced early in 1944, it has found immediate application in the treatment of various forms of tuberculosis. But streptomycin is not and must not be considered as a cure for tuberculosis.

It has its limitations. Most important of these is its toxic effect upon the eighth nerve and the development of resistance in the infecting agent upon prolonged treatment.

In the search for new antibiotics particular attention has been paid to agents that are more active than streptomycin, that are as active upon the streptomycin-resistant as upon the sensitive strains, and that allow, to a less extent than does streptomycin, the development of resistance. The discovery of neomycin pointed to the possibility of finding such antibiotics. Sooner or later other antibiotics will be found which are more effective than either and less toxic. The fact that in the various surveys on antibiotic production by micro-organisms the acid-fast bacteria are found to be among the most sensitive forms points to the possibility of the existence of such agents. Finding these is merely a matter of further search.

Further possibilities for improving the effect of streptomycin in tuberculosis are found in the combined use of two antibiotics or of an antibiotic and a synthetic compound. We can therefore look forward to a very bright future in the search for chemotherapeutic agents which will prove to be effective in the final eradication of tuberculosis.

\section{REFERENCES}

American Trudeau Society (1950). Amer. Rev. Tuberc., 61, 436. American Trudeau Society (1950). Amer.

142,650 .
Fanconi, G., and Löffler, W. (1948). Streptomycin und Tuberkulose. Benno Schwabe, Basel.

Feldman, W. H., Hinshaw, H. C., and Mann, F. C. (1945). Amer.

Rev. Tuberc. 52, 269.
Florey, H. W. Chain, E., Heatley, N. G., Jennings, M. A., Sanders, A. G., Abraham, E., P., and Florey, M. E. (1949). Antibiotics, Vols. 1 and 2 . Oxford University Press, London.

Hinshaw, H. C., and Feldman, W. H. (1945). Proc. Mayo Clin., 20, 313.

二-

Karlson, A. G., Gainer, J. H., and Feldman, W. H. (1950). Dis. Chest, 17, 493.

Medical Research Council (1948). British Medical Journal, 2, 769.

Medical Research and Hinshaw, H. C. (1949). Streptomycin and Dihydrostreptomycin in Tuberculosis. National Tuberculosis Association.

Smith, M. I., and McClosky, W. T. (1945). Publ. Hlth Rep., Wash., 60, 1129 .

Waksman S. A. (1947). J. Amer. med. Ass., 135, 478.

(1949). Streptomycin-Its Nature and Practical Application. Williams and Wilkins Co., Baltimore, Maryland. Hutchison, D., and Katz, E. (1949). Amer. Rev. Tuberc., 60, 78 .

As the result of changes made in the National Hospital Service Reserve since recruiting first opened last autumn, the Ministry of Health has now sent an up-to-date outline of the scheme to all hospital authorities. It has come to the Ministry's notice that some of those who served at first-aid posts in the last war-and would be ready to do so again-have held back from joining the National Hospital Service Reserve because they are under the impression that there will be separate recruiting for first-aid-post personnel. This is not the case. Unlike the arrangements in the last war, the first-aid posts will in future be linked directly to hospitals; therefore personnel for all emergency nursing work, whether in hospital wards or first-aid posts, will be recruited and attached to the hospitals themselves. As far as possible those members joining the Reserve who express a preference to serve at first-aid posts will be earmarked for this kind of work. By the end of June membership of the Reserve had risen to 3,225 , made up of 266 trained nurses and 2,959 auxiliaries. In supervising the organization of the Reserve, the Ministry has the guidance of a National Advisory Committee of sixteen members which includes representatives of the hospital authorities, St. John Ambulance Brigade, British Red Cross Society, Association of Hospital Matrons, Royal College of Nursing, and other bodies. 